\title{
Effect of Cooking Method on Wet Tensile Strength of Kozo Paper
}

\author{
Zhiyou Hant and Keiko Kida \\ Graduate School of Fine Arts, Tokyo University of the Arts*1 \\ Masaki Handa \\ Handa Kyuseido Co., Ltd \\ Masamitsu Inaba*2 \\ Graduate School of Fine Arts, Tokyo University of the Arts*1
}

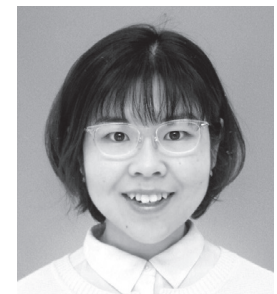

Zhiyou Hant

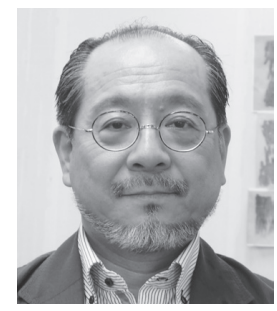

Masaki Handa

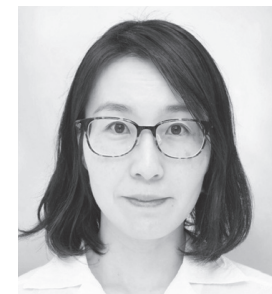

Keiko Kida

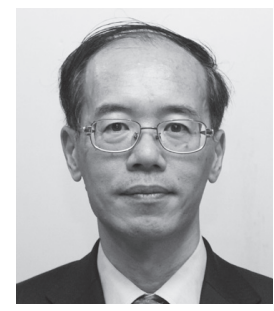

Masamitsu Inaba

\begin{abstract}
Usu-mino-gami (a kind of thin kozo paper) is frequently used as the first back lining paper of hanging scrolls in order to support the main paper with a painting or a work of calligraphy on it. For dying appropriate color, the paper is often treated with alkali mordant solution. However, current usu-mino-gami product received such comments from conservators that wet tensile strength is weak, and hard to handle. Therefore, improving wet tensile strength of kozo paper have to be required. In our previous paper, the effect of sheet forming method on wet tensile strength of usu-mino-gami has been investigated. In this paper the effect of cooking method on wet tensile strength of kozo paper was subsequently investigated. Wet tensile strength of kozo paper which made with different cooking conditions, was evaluated using Finch device. Kozo paper with different amount of parenchyma cell was also be made. The amount of parenchyma cell in pulp was measured with area ratio of parenchyma cell films between fibers on kozo sheet by using scanning electron microscope (SEM) images. According to the results, the increase of wet tensile strength and higher amount of parenchyma cell were observed with shorter cooking time, and lower concentration of cooking agent (alkaline). Furthermore, wet tensile strength of kozo paper increased when amount of parenchyma cell in pulp was higher.
\end{abstract}

Keywords : kozo paper, washi (Japanese paper), wet tensile strength, parenchyma cell, cooking method, alkaline concertation

\footnotetext{
${ }^{* 1}$ 12-8 Uenokoen, Taito-ku, Tokyo 110-8714, Japan

${ }^{* 2}$ E-mail : masa.inaba@nifty.com
} 


\section{Introduction}

There is a backing sheet that directly and stably supports a fragile main paper in Japanese mounted paintings. The main paper is very fragile in most cases, and is physically supported with first back lining paper, called, hada-ura-gami, especially with hanging scrolls, thin grade of mino-gami (usu-mino-gami) is commonly used as first lining paper. As first lining paper is usually dyed and pasted in mounting process, high wet strength is required. So, we have been studying production processes of first lining paper that will improve its wet strength. In our previous paper ${ }^{1}$, we used sheet samples prepared by different persons as well as with different sheet forming processes, determined their physical properties and found following results. Regarding sheet formation, usumino-gami made by late Kozo Furuta was the best, followed with one prepared by Satoshi Hasegawa, Furuta's disciple, and one by a beginner was the worst. This order corresponded to the order of functional evaluation on the performance of sheets at ash mordant dying. The sheet by Furuta had the highest wet tensile strength measured by Finch method. The sheet prepared of kozo stock washed in a bag before sheet forming and the sheet prepared of pulp from the top part of kozo branch had weaker wet strength. The sheet formation and the wet strength of a sheet tended to improve, when prepared in a later number of sheet forming cycle from the same batch.

The main components of washi raw stock are fiber and parenchyma cell. Morimoto reported followings, based on the paper by Imai and Ishikawa ${ }^{2)}$. "Bast fiber plant has two kinds of parenchyma cells, one of large oval shape and the other of relatively small round shape. Their micro-fibril is randomly aligned and their $a$-cellulose content is as high as about $60 \%$. As mitsumata, one of bast fiber plant, is rich with hemicellulose, gampi and kozo would be so as well. As parenchyma cell, especially of bast fiber plant, retains hemicellulose well after cooked, has good bonding capability. After dried, they

Table 1 Samples of Usu-mino-gami

\begin{tabular}{|c|c|c|c|c|c|c|c|}
\hline Sample* & $\begin{array}{l}\text { Produc- } \\
\text { tion Year }\end{array}$ & $\begin{array}{l}\text { Weight } \\
\text { ratio of } \\
\text { sodium } \\
\text { carbonate } \\
\text { to } \\
\text { bark/\%** }\end{array}$ & $\begin{array}{l}\text { Cooking } \\
\text { time / h }\end{array}$ & $\begin{array}{c}\text { Duration } \\
\text { before } \\
\text { washing/ h }\end{array}$ & $\begin{array}{l}\text { Grammage } \\
/ \mathbf{g} \cdot \mathbf{m}^{-2} \\
\text { (air dry) }\end{array}$ & $\begin{array}{l}\text { Thickness } \\
/ \mu \mathrm{m}\end{array}$ & $\begin{array}{r}\text { Density } \\
/ \mathbf{g} \cdot \mathbf{c m}^{-3}\end{array}$ \\
\hline $\mathrm{S} 2(\mathrm{H})$ & \multirow{4}{*}{2012} & $\begin{array}{c}10, \\
\text { then } 40\end{array}$ & $\begin{array}{c}1, \\
\text { then } 1 / 6\end{array}$ & \multirow{3}{*}{12} & $15.9 \pm 0.6$ & $55 \pm 4$ & $0.29 \pm 0.02$ \\
\hline $\mathrm{N} 2(\mathrm{H})$ & & 13 & 2 & & $14.8 \pm 0.9$ & $51 \pm 4$ & $0.29 \pm 0.02$ \\
\hline N2(F) & & & & & $17.7 \pm 1.1$ & $63 \pm 4$ & $0.28 \pm 0.03$ \\
\hline W2(H) & & 10 & 1 & 0 & $16.7 \pm 0.6$ & $58 \pm 3$ & $0.29 \pm 0.02$ \\
\hline $\mathrm{Fu}$ & $\begin{array}{c}\text { Before } \\
1994\end{array}$ & $(12-13)^{* * *}$ & $(1)^{* * *}$ & $(2-4)^{* * *}$ & $9.8 \pm 0.8$ & $48 \pm 4$ & $0.20 \pm 0.02$ \\
\hline
\end{tabular}

* The first four samples were prepared by Mr. Satoshi Hasegawa.

$\mathrm{S} 2(\mathrm{H})$ was prepared under strong cooking condition.

$\mathrm{N} 2(\mathrm{H})$ was prepared under normal cooking condition.

$\mathrm{N} 2(\mathrm{~F})$ was prepared from washed pulp $(\mathrm{N} 2(\mathrm{H}))$ in a cloth bag (Fukuroarai) with water

before sheet forming.

W2(H) was prepared under weak cooking condition.

Fu was prepared by Mr. Kozo Furuta, one of the best usu-mino-gami craftsmen ever.

** The amount of alkaline solution used in cooking process is around $15 \mathrm{~L} / \mathrm{kg}^{\circ}$ of bark ${ }^{5}$.

**** According to the survey of Yagihashi ${ }^{6}$. 
Table 2 Samples of kozo sheet

\begin{tabular}{|c|c|c|c|c|c|c|c|}
\hline \multirow{2}{*}{ Sample $^{*}$} & \multicolumn{2}{|c|}{ Cooking agent } & \multirow{2}{*}{$\begin{array}{l}\text { Cooking } \\
\text { time / h }\end{array}$} & \multirow{2}{*}{$\begin{array}{c}\text { Duration } \\
\text { before } \\
\text { washing / h }\end{array}$} & \multirow{2}{*}{$\begin{array}{c}\text { Grammage } \\
/ \mathbf{g} \cdot \mathbf{m}^{-2} \\
\text { (air dry) }\end{array}$} & \multirow{2}{*}{$\begin{array}{c}\text { Thickness } \\
\text { / } \mu \mathrm{m}\end{array}$} & \multirow{2}{*}{$\begin{array}{l}\text { Density } \\
/ \mathbf{g} \cdot \mathbf{c m}^{-3}\end{array}$} \\
\hline & Kind & $\begin{array}{l}\text { Concentra- } \\
\text { tion } / \%^{* *}\end{array}$ & & & & & \\
\hline $\mathrm{KC} 1$ & \multirow{10}{*}{$\mathrm{Na}_{2} \mathrm{CO}_{3}$} & \multirow{5}{*}{10} & 1 & \multirow{15}{*}{1} & $26.8 \pm 0.9$ & $64 \pm 3$ & $0.42 \pm 0.03$ \\
\hline $\mathrm{KC} 1.5$ & & & 1.5 & & $29.7 \pm 1.4$ & $64 \pm 6$ & $0.46 \pm 0.04$ \\
\hline $\mathrm{KC} 2$ & & & 2 & & $29.5 \pm 1.6$ & $68 \pm 5$ & $0.43 \pm 0.03$ \\
\hline $\mathrm{KC} 2.5$ & & & 2.5 & & $34.8 \pm 1.8$ & $66 \pm 4$ & $0.53 \pm 0.04$ \\
\hline $\mathrm{KC} 3.5$ & & & 3.5 & & $33.2 \pm 2.1$ & $68 \pm 4$ & $0.49 \pm 0.05$ \\
\hline KC1-13 & & 13 & 1 & & $33.3 \pm 1.3$ & $50 \pm 2$ & $0.67 \pm 0.06$ \\
\hline $\mathrm{KC} 1-20$ & & 16 & 1 & & $30.4 \pm 1.4$ & $49 \pm 2$ & $0.62 \pm 0.07$ \\
\hline $\mathrm{KC} 1-12-\mathrm{S}$ & & 12 & 1 & & $28.0 \pm 1.5$ & $52 \pm 2$ & $0.54 \pm 0.08$ \\
\hline KC1-14-S & & 14 & 1 & & $27.1 \pm 1.4$ & $53 \pm 1$ & $0.51 \pm 0.07$ \\
\hline $\mathrm{KC} 1-16-\mathrm{S}$ & & 16 & 1 & & $26.6 \pm 1.2$ & $53 \pm 2$ & $0.50 \pm 0.06$ \\
\hline KH0.5 & \multirow{5}{*}{$\mathrm{NaOH}$} & \multirow{5}{*}{10} & 0.5 & & $26.5 \pm 1.9$ & $59 \pm 5$ & $0.45 \pm 0.04$ \\
\hline KH1 & & & 1 & & $25.8 \pm 1.5$ & $62 \pm 3$ & $0.42 \pm 0.05$ \\
\hline KH1.5 & & & 1.5 & & $31.8 \pm 2.4$ & $65 \pm 3$ & $0.49 \pm 0.06$ \\
\hline $\mathrm{KH} 2$ & & & 2 & & $29.1 \pm 2.0$ & $58 \pm 4$ & $0.50 \pm 0.05$ \\
\hline KH2.5 & & & 2.5 & & $28.9 \pm 2.6$ & $60 \pm 5$ & $0.49 \pm 0.05$ \\
\hline
\end{tabular}

* Samples basically were made at the University of Tokyo, except samples with "-S " were made at Industrial Research Institute of Shizuoka Prefecture.

$* * 60 \mathrm{~g}$ of air dried barks are cooked in $1.8 \mathrm{~L}$ of alkaline solution.

Table 3 Screening duration for reducing parenchyma cells in kozo pulp

\begin{tabular}{|c|c|c|c|}
\hline $\begin{array}{c}\text { Cooking } \\
\text { agent }\end{array}$ & Lot & $\begin{array}{c}\text { Pulp yield } \\
\qquad \%\end{array}$ & Screening time / min \\
\hline \multirow{3}{*}{$\mathrm{Na}_{2} \mathrm{CO}_{3}$} & $1 \mathrm{st}$ & 75 & $\begin{array}{llllll}0, & 2.0, & 4.0, & 8.0, & 15, & 30\end{array}$ \\
\hline & 2 nd & 77 & 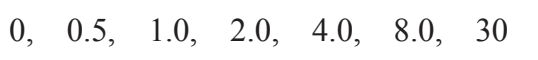 \\
\hline & $3 \mathrm{rd}$ & 71 & $\begin{array}{llllll}0, & 0.2, & 0.3, & 6.0, & 30, & 40\end{array}$ \\
\hline \multirow{2}{*}{$\mathrm{NaOH}$} & $1 \mathrm{st}$ & 64 & $\begin{array}{llllll}0, & 1.0, & 4.0, & 8.0, & 10, & 30\end{array}$ \\
\hline & 2nd & 56 & $0, \quad 0.1, \quad 0.25, \quad 10, \quad 40, \quad 100, \quad 180$ \\
\hline
\end{tabular}


collapse like membrane or film and cover large surface area. As they are rich with $a$-cellulose and have randomly aligned fibrils, resulting membrane or film would have high physical strength".

Imai and Ishikawa ${ }^{3)}$, using mitsumata, separated and reclaimed parenchyma cells from fiber stock by using two sieves of different mesh sizes, 40 mesh and 60 mesh. Then, they prepared hand sheets of different parenchyma cell contents, from 0 to $50 \%$, and measured their physical properties. They found that physical properties improved with increasing the parenchyma cell content in general. Folding endurance, burst factor and tear index, however, had their optimum values in between.

Okawa studied on kozo paper, and wrote that usu-mino-gami retained non-fiber cells, parenchyma cell particular, in itself, which worked as binder among fibers. He suggested that tensile strength of sheet would be improved with its presence though he did not present quantitative data.

Imai and Ishikawa ${ }^{2)}$ studied how parenchyma cell content was affected by cooking conditions. Mitsumata was cooked with sodium hydroxide solution (1\%) at two different temperatures, $150^{\circ} \mathrm{C}$ and $100^{\circ} \mathrm{C}$. After cooked at $100^{\circ} \mathrm{C}$, an index by which the number of parenchyma cells before cooking was regarded as 100 was reduced to 55 . When the temperature was increased to $150^{\circ} \mathrm{C}$, the index dropped to 21 . When sodium hydroxide concentration was increased from $2 \%$ to $50 \%$ under the same cooking duration of 60 minutes, the index of parenchyma cell greatly decreased from 76 to 36 . When cooked with $5 \%$ sodium hydroxide under atmospheric pressure, the index was 66 after 30 -minute-cooking, while it was 57 after 180-minute-cooking. They concluded that the index dropped rapidly at the beginning of cooking, and then it decreases rate slowed down.

In this paper, we report the effect of cooking conditions on wet strength of kozo paper.

\section{Experiment}

\subsection{Samples}

\subsubsection{Usu-mino-gami made by Hasegawa}

Samples were prepared in Hasegawa Washi Kobo, Mino City, Gifu Prefecture. White bark of Nasu kozo was cooked with sodium carbonate $\left(\mathrm{Na}_{2} \mathrm{CO}_{3}\right)$, and then was sheet formed as in Table 1.

$\mathrm{N} 2(\mathrm{H})$ is a sample cooked and sheet formed by Satoshi Hasegawa with his usual procedure. $\mathrm{N} 2(\mathrm{~F})$ is one in which the same stock was washed in a bag to remove parenchyma cells and fine fibers and then sheet formed, $\mathrm{S} 2(\mathrm{H})$ was cooked strongly, and $\mathrm{W} 2(\mathrm{H})$ was cooked weakly. Fu is the same sample used in our previous paper $^{1}$. As other samples were manufactured not in the same years, $\mathrm{N} 3(\mathrm{H})$ in the previous paper is different from $\mathrm{N} 2(\mathrm{H})$ in this paper.

\subsubsection{Kozo sheet with different cooking conditions}

As the samples by Hasegawa were made of pulp stocks cooked with different alkali concentrations for different cooking times, it was not possible to clarify their independent effects. To study the effect of alkali concentration, cooking time and cooking agents independently, 15 samples were prepared from kozo as in Table 2. The cooking agents were sodium carbonate and sodium hydroxide.

Kozo bark chips of Kochi Prefecture, cut $4 \mathrm{~mm}$ long, were cooked. The resulting pulp was beaten by PFI mill (5,000 rounds). Then, the stock was formed to sheet of which grammage was $30 \mathrm{~g} / \mathrm{m}^{2}$ a.d., according to JIS 8222:1998 Preparation of hand sheet for testing. In washi making, mucilaginous agent is usually used. As our kozo was already cut short, we did not used the agent. Most of sheets were made at the University of Tokyo. But, the sample having "-S" in their name were made in Industrial Research Institute of Shizuoka Prefecture. Although the setting of PFI mills was same, there might be some difference in beating performance between them.

\subsubsection{Kozo sheets of different parenchyma cell} contents

Air-dried chips (equivalent to $60 \mathrm{~g}$ b. d. or $70 \mathrm{~g} \mathrm{~b}$. d.) were cooked for an hour with sodium carbonate and sodium hydroxide respectively. The resulting pulp, each of them, was beaten by PFI mill (5,000 rounds) and then divided to 6 or 7 lots. According to JIS P8207:1998 Fractionation of pulp, fractionation was done using a fractionator by Kumagai Riki Kogyo Co. (KRK-2591). A pulp slurry $(1 \mathrm{~L})$ of which concentration was $1 \%$ was fractionated through 200 mesh wire, its opening being 75 $\mu \mathrm{m}$, for different times, ranging from zero to 180 minutes to remove parenchyma cell of which size was about 40 $\mu \mathrm{m} \times 30 \mu \mathrm{m}$ and to get several kinds of kozo pulp of different parenchyma cell contents. Hand sheets of which grammage was $30 \mathrm{~g} / \mathrm{m}^{2}$ were prepared from those fractionated pulp samples. Three lot volumes of pulp and two lot volumes of pulp were used for the fractionation as in Table 3.

\subsection{Experimental methods}

\subsubsection{Wet tensile strength}

As in the previous report ${ }^{1}$, Finch method was used. A sample sheet was immersed in potassium carbonate solutions of different concentrations, 0,44 , and $500 \mathrm{mmol} / \mathrm{L}$ respectively, for 20 seconds, and then its wet tensile strength was measured according to JIS P8135:1998.

\subsubsection{Area ratio of parenchyma cell film}

Using scanning electron microscope ( $\mathrm{S}-2460 \mathrm{~N}$ by Hitachi Co.), the enlarged picture of a sheet area $(21 \mathrm{~mm}$ 


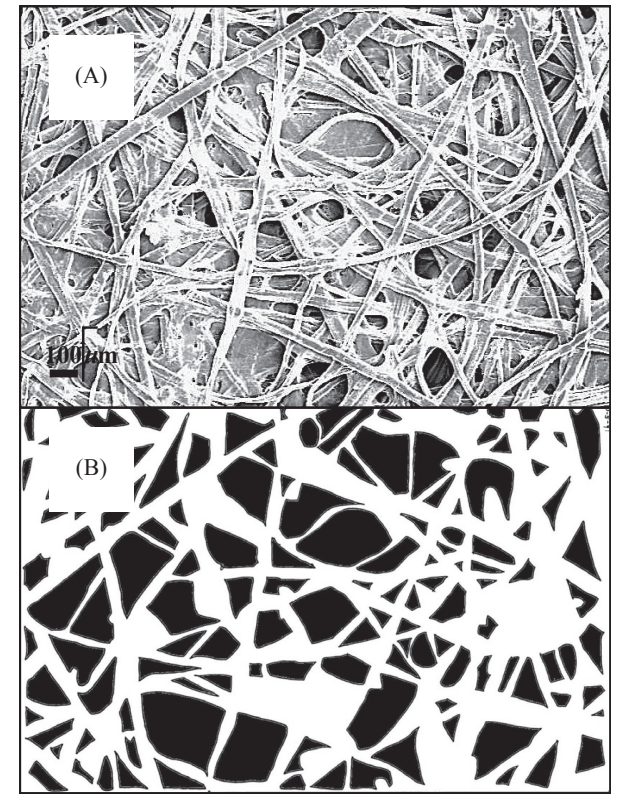

Fig. 1 Example for calculating area ratio of parenchyma cell films (sample of $\mathrm{N} 2(\mathrm{H}))$ : (A) scanning electron micrograph of kozo sheet; (B) tracing the areas of parenchyma cell films in scanning electron micrograph.

$\times 29 \mathrm{~mm}$ ) on its surface side as well as on its back side, was observed. Nine pictures for each side, were obtained (Fig. 1(A)). We assumed that the membrane- or filmlike area among fibers was of parenchyma cell. We traced outlines of parenchyma cells on a thin tracing paper off a scanning electron micrograph picture. The traced image was scanned by a scanner, and binarized by Image J software. Then, the enclosed area was measured (Fig. 1(B)). The ratio of the enclosed area against the total sheet area was defined as area ratio of parenchyma cell film.

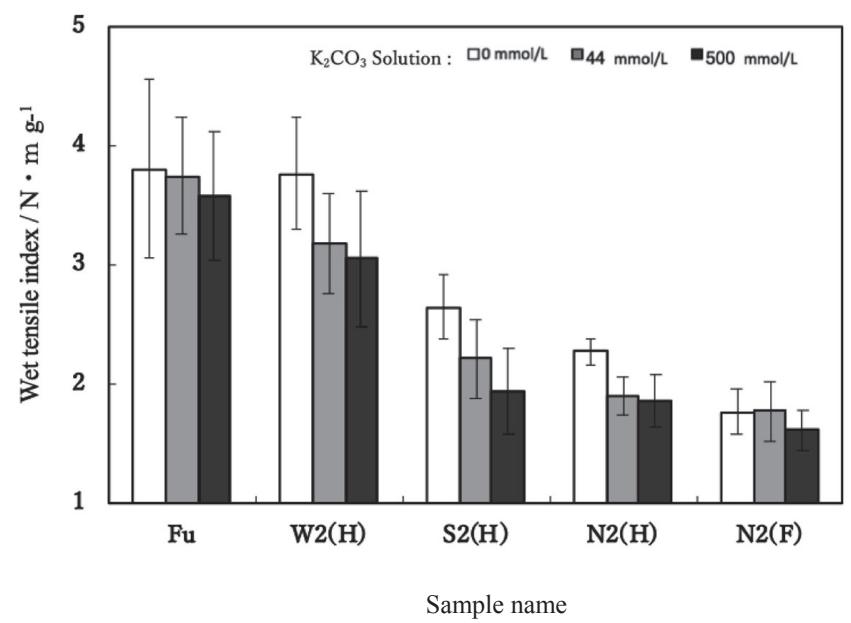

Fig. 2 Wet tensile strength of usu-mino-gami, the pulps of which were prepared under different cooking and washing conditions.
Area ratio of parenchyma cell film (\%)

$=\frac{\text { area of parenchyma cell films }}{\text { total sheet area }} \times 100$

\section{Result and discussion}

\subsection{Wet strength of usu-mino-gami}

3.1.1 The effect of cooking conditions and bag washing (Fukuro-arai)

Usu-mino-gami, samples which had different cooking conditions were immersed in three alkali solutions of different concentrations and their wet strength was measured. Fig. 2 summarizes the result. Sample Fu, which was prepared by Furuta, a master of hand sheet making, was the strongest as reported in the previous paper. W2 (H), weakly cooked, had wet strength close to that of Fu. N2 (H), normally cooked, and S2 $(\mathrm{H})$, strongly cooked, had almost the same strength. Their cooking conditions might not be adequate.

N2 (F) 1n this paper, which was a bag-washed N2(H) (normally cooked) to remove parenchyma cells and fine fibers, lost less strength than N2(F) did in the previous paper ${ }^{1)}$.

3.1.2 The effect of area ratio of parenchyma cell film As reviewed in Chapter 1, Imai and Ishikawa ${ }^{3)}$ reported that paper made from mitsumata increased its strength with higher parenchyma cell content ratios. We calculated each area ratio of parenchyma cell film of our sheet samples made from kozo, and plotted against its wet strength measured under potassium carbonate solution $(44 \mathrm{mmol} / \mathrm{L})$ (Fig. 3). Sample Fu and Sample W2 $(\mathrm{H})$, both of which had high wet strength, were high in the area ratio of parenchyma cell film. Samples S2(H), $\mathrm{N} 2(\mathrm{H})$ and $\mathrm{N} 2(\mathrm{~F})$, each of which had low wet strength, had less area ratio of parenchyma cell film either, and

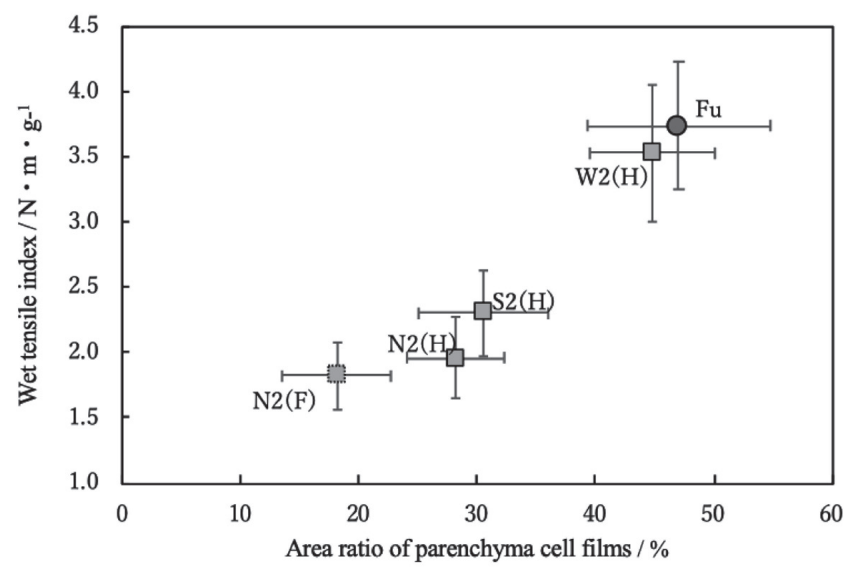

Fig. 3 Relationship between wet tensile strength and area ratio of parenchyma cell films of usu-mino-gami, the pulps of which were prepared under different cooking and washing conditions. 
plotted in a bottom left area in the graph. Therefore, the relationship between area ratio of parenchyma cell film and wet strength of kozo paper became clear. Compared with the sample of $\mathrm{S} 2(\mathrm{H})$ with strong cooking condition, the sample of $\mathrm{N} 2(\mathrm{H})$ with normal cooking condition had lower area ratio of parenchyma cell film. The reason of it could be considered with inappropriate cooking condition setting. Sample of N2(F), which was prepared from washed pulp $(\mathrm{N} 2(\mathrm{H}))$ 1n a cloth bag, had lower area ratio of parenchyma cell film than sample of N2(F), however, the wet strength of samples are hardly any difference with each other.

Though the actual cooking record of Sample Fu, made by Furuta, is unknown, Yagihashi researched his cooking condition which was in Table 1. His alkali concentration would be $12-13 \%$, higher than one by Hasegawa, which was $10 \%$. Though their cooking times were the same each other, their duration times before washing were not the same. The findings suggest that to get usu-mino-gami

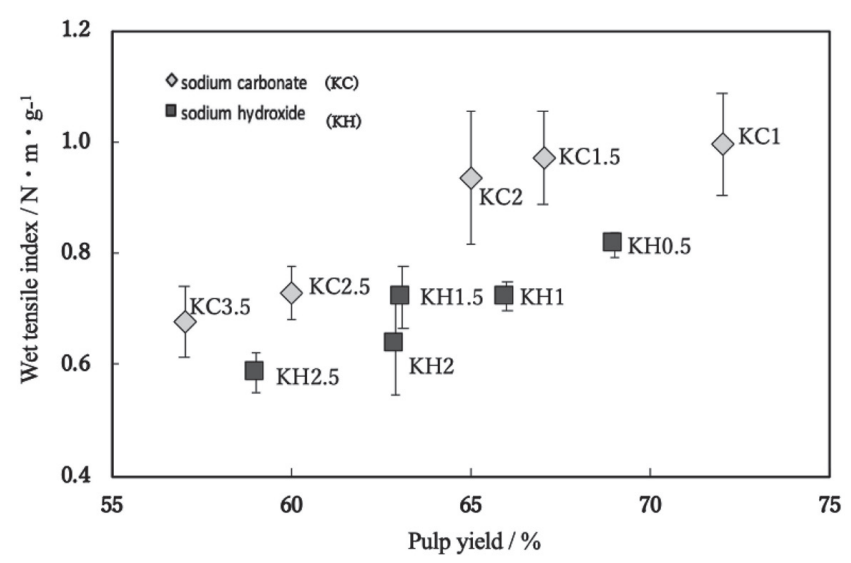

Fig. 4 Wet tensile strength of kozo handsheets, the pulps of which were prepared under the same cooking conditions but had different yields.

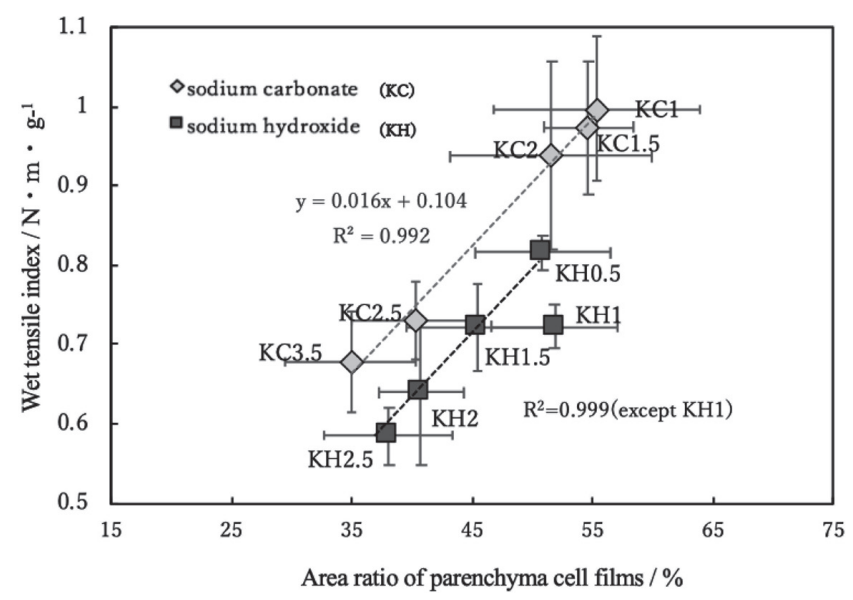

Fig. 6 Relationships between wet tensile strength and area ratio of parenchyma cell films of kozo handsheets, the pulps of which were prepared under different conditions and had different yields. of high wet strength, it would be better to shorten the cooking time that Hasegawa normally used in $(\mathrm{N} 2(\mathrm{H}))$.

3.2 The effect of cooking conditions on wet strength of kozo sheet

\subsubsection{The effect of cooking time}

Kozo sheet samples which had different cooking conditions, listed in Table 2, were taken to measure their wet tensile strength (Fig. 4). With samples cooked at the same alkali concentration, one, which was cooked for a longer time and had a less pulp yield, gave weaker wet tensile strength. Samples which were cooked with sodium hydroxide, strongly alkaline, gave less wet tensile strength than ones cooked with sodium carbonate, less alkaline, compared at the same pulp yield value.

\subsubsection{The effect of alkali concentration}

As in Fig. 5, with samples cooked for the same duration of time with different alkali concentrations, there was a trend that the higher alkali concentration reduced pulp yield and wet tensile strength, though data were

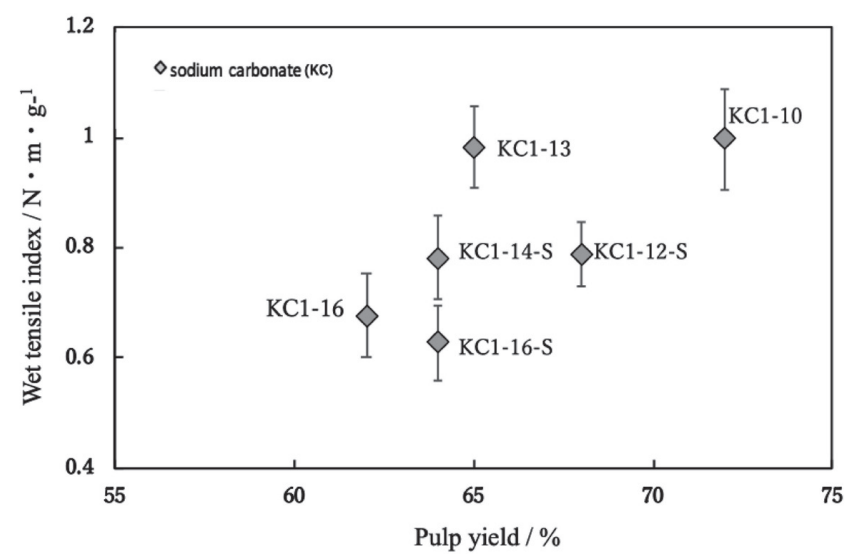

Fig. 5 Wet tensile strength of kozo handsheets, the pulps of which were prepared under different conditions and had different yields.

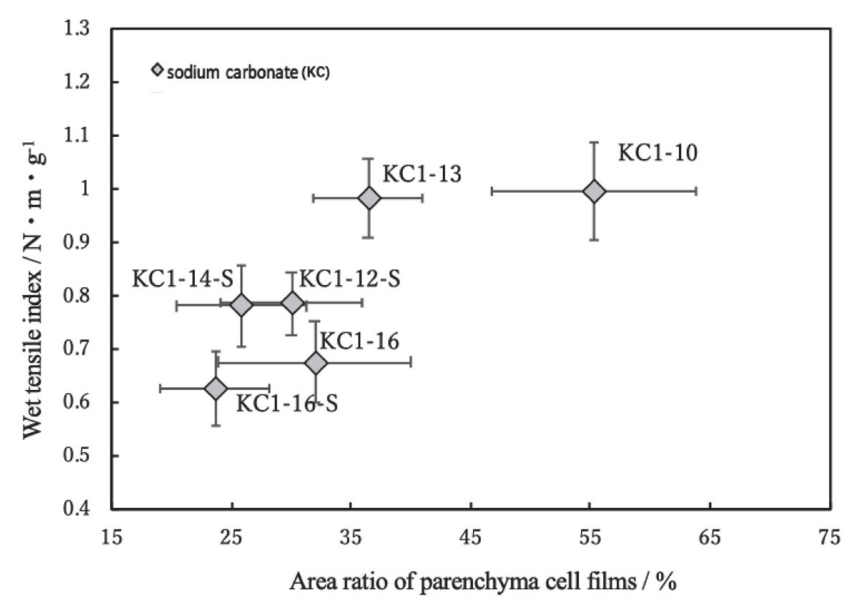

Fig. 7 Relationship between wet tensile strength and area ratio of parenchyma cell films of kozo handsheets, the pulps of which were prepared with sodium carbonate at concentrations. 

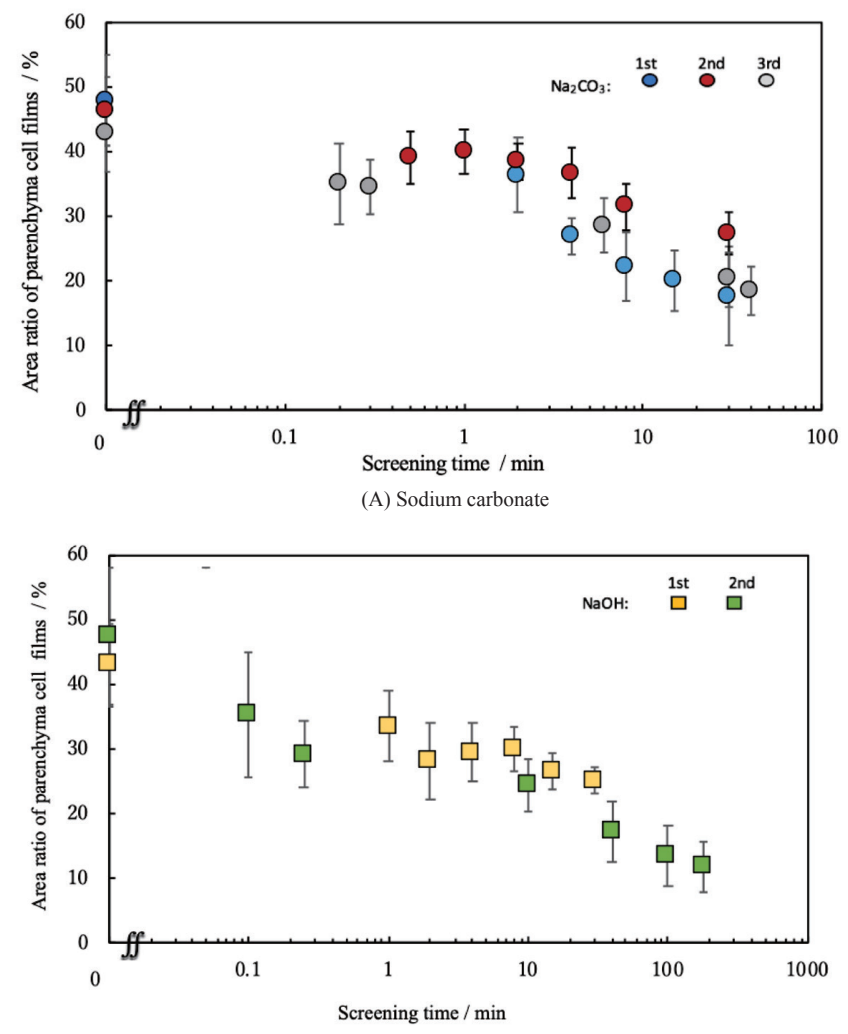

(B) Sodium hydroxide

Fig. 8 Area ratio of parenchyma films of kozo handsheets, the pulps of which were prepared with sodium carbonate (A) and sodium hydroxide (B) at different screening times.

scattering ${ }^{* 1}$.

3.2.3 The effect of area ratio of parenchyma cell film

Fig. 6 depicts the relationship between the area ratio of parenchyma cell film and the wet tensile strength. The group of samples, cooked under the same alkali concentration for different durations of time, had a good straight regression line between the two parameters, though one exception was KH1, one-hour cooking with sodium hydroxide. The regression coefficient was 0.992 for the sodium carbonate group and 0.999 for the sodium hydroxide group. When compared at the same area ratio of parenchyma cell film, ones cooked with sodium carbonate had higher wet tensile strength than ones cooked with sodium hydroxide. The fact suggests that the type of alkali might be influential to hemicellulose content in pulp and damage caused on fiber, and it shows not only parenchyma cell, but also other factors might be influen-

*1 The sample having "-S" in their name were made in Industrial Research Institute of Shizuoka Prefecture. Although the setting of PFI mills was same, there might be some difference in beating performance between them.

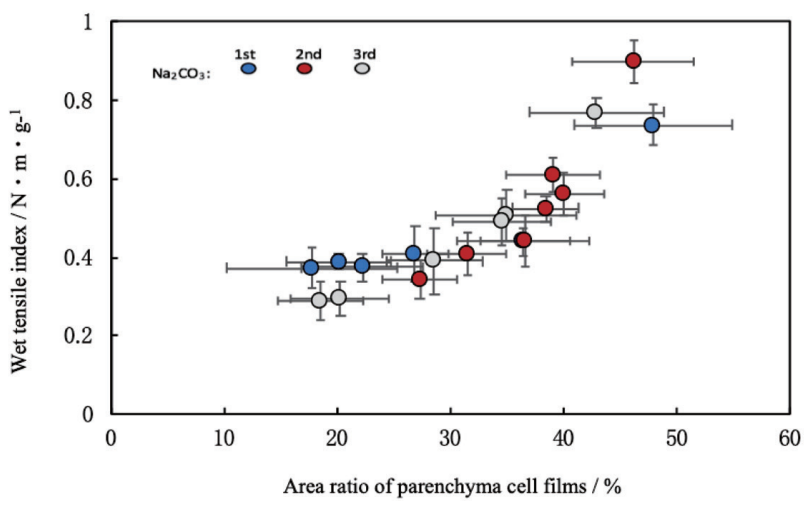

(A) Sodium carbonate

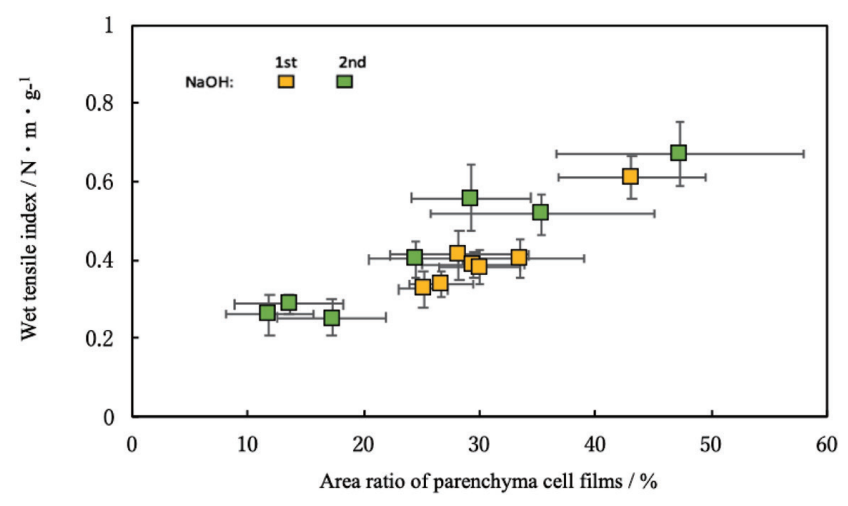

(B) Sodium hydroxide

Fig. 9 Rationships between area ratio of parenchyma cell films of kozo handsheets and wet tensile strength of kozo handsheets, the pulps of which were prepared with sodium carbonate $(\mathrm{A})$ and sodium hydroxide (B).

tial to wet strength for same alkali under different cooking time.

Fig. 7 shows the relationship between area ratio of parenchyma cell film and wet strength for samples, which cooked for the same duration of time under different alkali concentrations. High alkali concentrations tended to reduce area ratio of parenchyma cell film and wet tensile strengths as well.

3.3 Effect on wet strength of kozo sheet by the change of area ratio of parenchyma cell film by using classification with screen

\subsubsection{Area ratio of parenchyma cell film}

We reported in the last chapter that wet strength of sheet correlated to area ratio of parenchyma cell film in sheet. That area ratio, however, was varied by changing the cooking condition, which might be affected the ratios of components in and the degree of damage on fiber. So, we fractionated the same pulp stepwise for different durations of time to get pulp samples of different parenchyma cell contents, while the ratios of components in and the degree of damage on fiber were still identical. As in Fig. 8, we took two and three lot volumes of pulp for 
fractionation, and each lot had 6-7 levels of the area ratio of parenchyma cell film. The area ratio decreased along with extending fractionating time. It, however, went down only to $10 \%$, even after 180 - minute- fractionation.

\subsubsection{The relationship between area ratio of} parenchyma cell film and wet strength

The kozo sheets of different area ratios of parenchyma cell film were tested to get their wet strength (Fig. 9). As the ratio went down, so was the wet strength. The reduction rate of the wet strength, however, became smaller. As parenchyma cell is influential to wet strength of kozo sheet, the cooking condition which retains as much parenchyma cell as possible is preferable.

\section{Conclusion}

We studied how the wet strength of kozo sheet was affected by cooking conditions. Among usu-mino-gami samples that were prepared by Hasegawa under different alkali concentrations and had different cooking conditions, one mildly cooked had a good wet strength and retained a high area ratios of parenchyma cell film.

To clarify further the effect of cooking conditions, two groups of kozo sheet samples were prepared, one cooked under the same alkali concentration for different durations of time and the other under different alkali concentrations for the same cooking time. In the group of fixed alkali concentration, two kinds of alkali, sodium carbonate and sodium hydroxide, were used. Shorter cooking time gave higher wet strength and higher area ratios of parenchyma cell film, and there was a linear relationship between the two parameters in both groups. Compared at the same area ratio of parenchyma cell film, ones cooked with sodium carbonate had higher wet strength than ones with sodium hydroxide. In the group of fixed cooking time, ones cooked with lower concentrations had higher wet strength and retained more parenchyma cells.

As different cooking condition might cause unknown effects on fiber other than content of parenchyma cell, and might affected wet strength itself. Kozo pulp made with the same cooking condition and then beaten was fractionated through a sieve of which opening was 75 $\mu \mathrm{m}$ to reduce parenchyma cell content, from which sheets were made. So, kozo sheets of different area ratio of parenchyma cell film were obtained. The wet strength went down as area ratio of parenchyma cell film got less, nevertheless, the declines of wet strength gradually flattened as the ratio got less. It was concluded that to have kozo paper of better wet strength, the cooking condition should be as weak as possible, which would increase parenchyma cell content of pulp stock.

Acknowledgement

We sincerely thank Mr. Satoshi Hasegawa of Hasegawa Washi Kobo for his help, and Professor Akira Isogai and Specially-appointed Professor Minoru Kimura, The University of Tokyo, Laboratory of Bionanomaterials and Cellulose Sciences for their help making kozo sheets.

A part of this research has been funded by JSPS Grant-in-aid for Scientific Research, Basic Research Program (B) (23300323) and Yoshida Manabu Fund for Cultural Heritage「Study of Improvement Kozo Paper Wet Strength in Conservation of Culture Properties $\rfloor$. We sincerely thank them for their supports.

\section{References}

1) Inaba, M., Hasegawa, S., Handa, M., Enomae, T., Takashima, A., Han, Z. and Someya, S. : Usu-minogami no Sitsujun-tsuyosa heno Shoshi-houhou no Eikyo (Effect of Sheet Forming Method on Wet Tensile Strength of Usu-mino-gami (Japanese Kozo Pape))), JAPAN TAPPI JOURNAL, 73 (6), 559-574 (2019)

2) Morimoto, M. : 5 sho : Himokuzai wo Kami ni riyousuru Gijutsujyo no Ryuiten (Chapter 5:Consideration of non-wood technology uses on paper), Kankyo no 21seiki ni Ikiru Himokuzai Shigen (Bring out Non-wood Fibres in the $21^{\text {st }}$ century of the Environment, Unishuppan Co. (1999) 163-212

3) Imai, H. and Isikawa, H. : Mitsumata no Kenkyu (9) Mitsumata no Jusaibo ni tsuite (Study on Gampi No.9 Parenchyma Cell of Gampi), Naikaku Insatsukyoku Kenkyuhoukoku (Research Bulletin of National Printing Bureau), (3), 9-19 (1938)

4) Okawa, A. : Kozo Mitsumata Gampi Sen'i no Kanbetsu (Identification of kozo, mitsumata and gampi fiber), Kami Sozai Bunkazai (Monjyo, Tenseki, Seikyo, Ezu) no Nendai Suitei ni kansuru Kisoteki Kenkyu (The Fundamental Study for the Estimated Era of Paper Cultural Properties (Documents, Classical Books, the Sacred teachings, Drawings), edited by Tomita, M., 2003-2005 Grant-in-Aid for Scientific Research (A) Research Report, University of Toyama, (2008) 4552

5) Uyeda, T., Saito, K., Inaba, M. and Okawa, A. : The Effect of Cooking Agents on Japanese Paper, Restaurator, 20 (3-4), 19-125 (1999)

6) Yagihashi, S. : Dai 12 sho Mino-gami (Chapter 12 Mino-gami), Washi Fuudo $\cdot$ Rekishi $\cdot$ Gihou (Japanese Paper Natural Environment, History and Technique), Kodansha Co. (1981) 86-92 